Article

\title{
Impact of Using Organic Yeast in the Fermentation Process of Wine
}

\author{
Balázs Nagy ${ }^{1}$, Zsuzsanna Varga ${ }^{2}$, Réka Matolcsi ${ }^{1}$, Nikolett Kellner ${ }^{1}{ }^{1}$, Áron Szövényi ${ }^{1}$ and \\ Diána Nyitrainé Sárdy $1, *$ (1)
}

1 Faculty of Horticultural Science Department of Oenology, Szent István University, 1118 Budapest, Hungary; nagy.balazs@szie.hu (B.N.); matolcsireka@gmail.com (R.M.); kellner.nikolett@szie.hu (N.K.); szovenyi.aron.pal@szie.hu (Á.S.)

2 Faculty of Horticultural Science Department of Viticulture, Szent István University, 1118 Budapest, Hungary; varga.zsuzsanna@szie.hu

* Correspondence: nyitraine.sardy.diana.agnes@szie.hu

check for updates

Citation: Nagy, B.; Varga, Z.;

Matolcsi, R.; Kellner, N.; Szövényi, Á.; Nyitrainé Sárdy, D. Impact of Using Organic Yeast in the Fermentation

Process of Wine. Processes 2021, 9, 155. https://doi.org/10.3390/pr9010155

Received: 12 November 2020

Accepted: 12 January 2021

Published: 15 January 2021

Publisher's Note: MDPI stays neutral with regard to jurisdictional clai$\mathrm{ms}$ in published maps and institutional affiliations.

Copyright: (C) 2021 by the authors. Licensee MDPI, Basel, Switzerland. This article is an open access article distributed under the terms and conditions of the Creative Commons Attribution (CC BY) license (https:// creativecommons.org/licenses/by/ $4.0 /)$.

\begin{abstract}
The aim of this study was to find out what kind of "Bianca" wine could be produced when using organic yeast, what are the dynamics of the resulting alcoholic fermentation, and whether this method is suitable for industrial production as well. Due to the stricter rules and regulations, as well as the limited amount and selection of the permitted chemicals, resistant, also known as interspecific or innovative grape varieties, can be the ideal basic materials of alternative cultivation technologies. Well-designed analytical and organoleptic results have to provide the scientific background of resistant varieties, as these cultivars and their environmentally friendly cultivation techniques could be the raw materials of the future. The role of the yeast in wine production is crucial. We fermented wines from the "Bianca" juice samples three times where model chemical solutions were applied. In our research, we aimed to find out how organic yeast influenced the biogenic amine formation of three important compounds: histamine, tyramine, and serotonin. The main results of this study showed that all the problematic values (e.g., histamine) were under the critical limit $(1 \mathrm{~g} / \mathrm{L})$, although the organic samples resulted in a significantly higher level than the control wines. The glycerin content correlated with the literature values, since it is well known that the glycerin-pyruvic acid transformation results in a $6-10 \mathrm{~g} / \mathrm{L}$ concentration.
\end{abstract}

Keywords: wine fermentation; organic yeast; innovative grape varieties; organic wine; biogenic amine; polyphenol content

\section{Introduction}

Due to the recent trends in environmentally friendly and health conscious food consumption, organic products and organic wines produced in sustainable farming systems are gaining larger significance all over the world. Thus, organic yeast has also appeared among oenological products. Organic yeast is a selected yeast propagated and dried with biological methods. Due to the substrate used for the propagation, organic yeast originates from regulated organic production. Organic wine production requires special attention, not only in the vineyard, but in the whole winery. The process of drying is carried out carefully, and is regulated by the relevant EU rules for organic production [1] and the official NOP standards in the US. The packaging of organic yeast is also a certified organic material. According to the rules and standards, organic yeast production utilizes substrates deriving only from organic agriculture and GMO-free materials.

Several studies focus on the effects of organic yeasts, especially on the amount of biogenic amine, which is a beneficial, physiologically active compound in organic wines.

Yeast is an oval-shaped unicellular fungus with a eukaryotic structure, which is more developed than that of a prokaryotic organism. 
During the alcoholic fermentation performed by yeasts, the sugar content of grape juice converts into ethanol, carbon dioxide, and heat energy [2]. In the first stage, yeast cells are multiplying, which requires oxygen, but the fermentation itself is an anaerobic process [3].

For the optimal course of alcoholic fermentation, several parameters in the juice (e.g., carbon resources and nitrogen) and ambient conditions (e.g., proper temperature) are crucial. A lack of nutrients can result in fermentation problems, such as slacking or stuck fermentation. Among the yeast nutrients, the following factors have an important role: nitrogen for protein conversion, phosphorus for cell respiration, minerals, and trace elements. During fermentation, yeasts require optimal feeding. There is a significant difference between the nutrient solutions for organic and conventional yeasts, and this is the prime factor in the variability of conventional and organic stocks.

Traditionally, yeast is propagated on black treacle, which is a side-product of sugar refining. The required additional nitrogen is provided artificially in an inorganic form. Synthetic vitamins, minerals, and effervescence inhibitors (e.g., paraffin oil) are also applied. These are not permitted compounds in organic food products. The $\mathrm{pH}$ values are modified with acids (e.g., sulfuric acid) and bases (e.g., sodium hydroxide). Traditional yeast production leads to the formation and residuals of the following chemicals: sulfuric acid, ammonia, phosphates, and synthetic oils. With the production of $1 \mathrm{~kg}$ yeast, $380 \mathrm{~kg}$ of slowly degradable waste gets into the water [4]. Organic yeast stocks can emphasize the characteristics of the variety and the terroir. They are produced in an environmentally friendly method without additional chemicals. Every applied microorganism and material is guaranteed GMO-free. The substrate used for the propagation of the yeast derives from certified organic agriculture. This substrate contains all the necessary nutrients, so it does not require any artificial addition.

Organic producers apply digested grain, which has an advantage over black yeast, namely, it provides enough nitrogen. Additional nitrogen is necessary only in a few cases, and it is provided in the form of whey or beer yeast. Organic sunflower oil works as an effervescence inhibitor. A pH correction and adjunct materials (e.g., artificial vitamins and inorganic salts) are not necessary.

Unlike in case of the conventional method, inorganic nitrogen, sulfuric acid, and ammonia are forbidden in organic yeast production. Synthetic effervescence inhibitors are not permitted either. For $\mathrm{pH}$ correction, sodium carbonate, citric acid, and lactic acid are allowed. Potato starch can function as filter, and sunflower oil as effervescence inhibitor. Since organic yeasts are not leached during the production, and only steam is applied, disinfectants are not necessary. Thus, no steps of the process produce any wastewater. This fermentation substrate is also suitable for other products, such as organic beverages.

Cells of organic yeast grow slower, and they require more resources. Consequently, their yield is lower, and their price is higher [5]. That is why conventional yeasts are still widely applied [6].

The term directional fermentation in oenology means the application of selected wine yeast stocks. The ideal process of alcoholic fermentation requires several other parameters, such as temperature, carbon source, and nitrogen. Grape juice contains the necessary nutrients for the process. A lack of nutrients can result in slacking or stuck fermentation. Nitrogen is especially significant. If there are not enough nitrogen resources for the yeast in the juice, it could cause fermentation problems (e.g., slacking or a stuck process). Moreover, it will increase the chance of hydrogen sulfide production during fermentation, which will lead to certain taste and odor defects (Böckser) [7,8].

The first studies on the biogenic amine content of Hungarian wines were published by Kállay et al. [9]. Biogenic amines consumed by food are degraded in the intestines, frequently by $\mathrm{N}$-acetylation or $\mathrm{N}$-methylation, with the involvement of the diamine oxidase (DAO) or monoamine oxidase (MAO) enzyme system. The role of MAO is to prevent these biogenic amines from entering the vascular system. Alcohol or certain widely used antidepressants inhibit MAO, so biogenic amines can accumulate to toxic levels in the 
body [10]. The effects of the biogenic amines studied in our recent publication are detailed below [9,11-14]:

- Methylamines: Methylamines are consumed via food, and consist of choline, carnitine, betaine, trimethylamine N-oxide (TMAO), and phosphatidylcholine [15]. Choline is an essential nutrient, which is present in higher amounts in egg yolk and liver. Together with betaine, it has several physiological functions. A high TMAO level of blood can prevent hyperammonemia, and it functions as osmo-protectants in case of osmotic stress [16]. TMAO reduces the neurotoxicity of glutamate, which is related to myocardial infarction and stroke [17]. In spite of these facts, it can be detected in higher levels in case of diabetes, Alzheimer's disease, and cardiovascular diseases. Its main function in the human body is the regulation of glucose transport in adipose cells, and supposedly the stimulation of the release of neurotransmitters through sodium channels of the nervous system. Neurotransmitters have a significant role in the transport mechanisms through the plasma membrane.

- Ethylamine: Ethylamine is a component of mammalian, including human, urine. According to observations, it is excreted in higher amounts in patients with liver and kidney disease and with damage to the central nervous system [18]. It can be detected in plants, food products, animal waste, and even in tobacco smoke. In human physiology, it is connected to anesthetics, such as ketamine, which is a well-known NDMA-antagonist (N-methyl-d-asparaginate-antagonist), and recreational drugs, for example phencyclidine. NDMA is a neurotransmitter, which can substitute glutamate, while ethylamine is a possible precursor for ketamine [18].

- Histamine: Derives from histidine. The industry applies it scarcely: it can be a potential ingredient of pesticides and certain veterinary medicinal products. It is synthetized in tissues of living organisms, when allergens and antibodies meet, but it can be consumed via food as well. Histamine has both positive and negative properties regarding its effects on human physiology, depending on the way it enters the body. Its primary function lays in the allergic and inflammatory reactions. It participates in brain functions, and as a stimulus transmitter in the nervous system. It also has a significant role in indigestion (e.g., gastric acid production, intestinal motility, and mucosal functions), in the development of immune responses, or in the enhancements of the formation and metastases of tumors. Larger amount of histamine intake can cause an allergic reaction. Approximately $1 \%$ of the population has histamine intolerance (disorder in degradation and accumulation). Histamine poisoning is caused by consuming foods that are too high in histamine, for which histamine intolerance metabolic disorders are responsible, which can occur even after the intake of small amounts [19]. Symptoms include (migraine) headaches, flushing, runny or stuffy nose, arrhythmia, low blood pressure, digestive problems (such as diarrhea), or hives. Relief of symptoms can be achieved by a low-histamine diet, namely products with a lot of histamine should be avoided [20,21]. Larger amounts are contained in smoked foods, chocolate, and red wines.

- Tyramine: Tyramine is formed from tyrosine. It is a side product of the fermentation and decomposition processes; it functions as a neurotransmitter in the human body, and is a metabolite of Escherichia coli. It can be found in large quantities in the basal ganglia and in the limbic system, so supposedly tyramine is connected to behavior and emotions [22]. It is a precursor in dopamine synthesis [23,24], which is a neurotransmitter, neuroendocrine-transmitter, and neurohormone. It is also called the reward hormone for its significance in the "reward mechanism" [25]. The following food products contain high amounts of tyramine: smoked, fermented or marinated fish and meat, fermented dairy products (tyramine derives from the Greek word "cheese"), fermented vegetables (for example sauerkraut), chocolate, various fruits and vegetables (banana, coconut, raisin, beans, etc.), and even yeast. Consuming large amounts of food with a high tyramine content can significantly raise blood pressure (even by $30 \mathrm{Hgmm}$ or more). The tyramine concentration in wine $(\sim 25 \mu \mathrm{g} / \mathrm{g})$ 
is considerably lower than in cheese (even $2000 \mu \mathrm{g} / \mathrm{g}$ ). Tyramine can cause serious health problems with people taking certain antidepressants (e.g., monoamine oxidase inhibitors).

- Serotonin: Serotonin is a monoamine neurotransmitter derived from L-tryptophane. It is a basic compound for the pharmaceutical industry, for example in antidepressant production. It has effects on the blood pressure, sleep and sexual behavior, state of arousal, and it also affects the manifestation of aggression. If a problem occurs in the serotonergic system, several diseases in the nervous system can be detected: depression, generalized anxiety disorder, obsessive-compulsive disorder, post-traumatic stress disorder, phobias, and epilepsy. Abnormally low serotonin levels lead to depression, which can result in suicide. High levels of serotonin have positive effects on health, such as improved perceptual ability and general well-being [26]. MDMA (3,4-methyl-enedioxy-methamphetamine) consumption comes with significant release of dopamine and serotonin [27]. During banana ripening, a large amount of serotonin is produced as well.

- Putrescine: Putrescine is a cadaverine-related polyamine, which smells reminiscent of pepper. Industrial utilization: catalyst in resin technology, compound in medicines for hypertrophic scars after breast augmentation surgeries, and insect attractants. It promotes cell division in smaller doses, but in larger amounts it extends to toxic decomposition products. It affects reproduction (spermatogenesis), functions as a nerve protector, but also has significance in tumorigenesis. During the preparation of fatty foods on higher temperatures, putrescine can convert into N-nitroso pyrrolidine, which is a carcinogenic compound [28]. It is produced in both living and dead organisms. It is responsible not only for the unpleasant smell of carcasses but bad breath as well. Cheese $(1560 \mathrm{mg} / \mathrm{kg})$ and fermented vegetables $(549 \mathrm{mg} / \mathrm{kg})$ contain a high amount of it [29].

- Phenethylamine: Supposedly, phenethylamine (PEA) regulates the effectiveness of nerve cell connections (neuromodulator), and it is also a neurotransmitter [30]. It often can be found in food, especially in fermented products. Almonds and chocolate, and even tobacco contain high amounts of phenethylamine. Typically, people with schizophrenia have high levels of it in the urine, while children with attention-deficit hyperactivity disorder (ADHD) have low levels of PEA. There is no verified cure for ADHD [31], but a study states that PEA intake relieves symptoms almost instantly [32]. At the same time, it gets into the brain only in small doses, because monoamine oxidase-b converts it to phenylacetic acid. In certain cases, phenethylamine produced by the human body has similar effects as amphetamine [32,33].

- Cadaverine: Cadaverine is a foul-smelling ("death smell") diamine compound that is produced by the putrefaction of animal tissue, by the hydrolysis of proteins, although living organisms can emit it as well. Primarily, it was detected in bacteria; by now, it has been found in plant organs [34], for example in soy bean, chick peas, etc. It shows an elevated level in urine of persons with lysine degradation disorders. The pharmacological effects of cadaverine include low blood pressure, bradycardia (low heart rate), stiffness, or partial paralysis of the limbs [35]. Del Rio et al. [36] (2019) emphasized that sufficient information about toxicity is not available, but the NOAEL value (No Observed Adverse Effects Level) of laboratory experiments with rats proved a daily $180 \mathrm{mg} / \mathrm{kg}$ of body weight. Other authors measured the LOAEL (Lowest Observed Adverse Effect Level) values of cadaverine regarding cell cultures, which was proved to be $510.89 \mathrm{mg} / \mathrm{kg}$. In case of putrescine LOAEL, it was $881.5 \mathrm{mg} / \mathrm{kg}$. This value is significantly lower than in previous presentations ( $255.45 \mathrm{mg} / \mathrm{kg}$ for total biogenic amine and $2000 \mathrm{mg} / \mathrm{kg}$ for cadaverine) [37,38]. Cheese can contain cadaverine in large amounts $(3170 \mathrm{mg} / \mathrm{kg})$, but fish is also a significant source $(1690 \mathrm{mg} / \mathrm{kg})$. 


\section{Materials and Methods}

The role of the yeast in wine production is crucial. In this study we wanted to find out what kind of "Bianca" wine can be produced when using organic yeast, what are the dynamics of the resulting alcoholic fermentation, and whether this method is suitable for industrial production as well.

\subsection{Materials}

We fermented wines from the "Bianca" juice samples three times where model chemical solutions were applied. The initial level of chaptalization was $20.6 \mathrm{MM}^{\circ}$ (sugar degree of the must), and the initial level of titratable acidity was $6.2 \mathrm{~g} / \mathrm{L}$. For the fermentation process, $2 \mathrm{~L}$ capacity glass carboys were used, and inoculation happened with $20 \mathrm{~g} / \mathrm{hL}$ organic yeast. Wine nutrient salt was added in $15 \mathrm{~g} / \mathrm{hL}$ doses in the middle and at the end of the fermentation process. The control sample was inoculated with the yeast Uvaferm $\mathrm{CS} 2$, at $20 \mathrm{~g} / \mathrm{hL}$, and the nutrient salt Uvavital was added mid-fermentation and at the end.

\subsection{Chemical Analyses}

There are multiple methods available to measure the level of biogenic amines. Due to the development of the analytical techniques, we have effective column chromatography methods (HPLC and IEC) and overpressure layer chromatography (OPLC) procedures at our disposal. Capillary electrophoresis methods are all suitable for defining the amines. The HPLC technique is suitable for processing the precise and high quantity sampling data. We implemented practices used in everyday life to examine the acids in the wine:

- titratable acid content-regulated by the Hungarian Standards Institution bearing the serial number MSZ 9472-86;

- $\quad \mathrm{pH}$ measurement using a combined glass electrode-MSZ-14849-79;

- malic acid content-using the Boehringer Mannheim enzyme test and spectrophotometry;

- citric acid content-using the Boehringer Mannheim enzyme test and spectrophotometry;

- lactic acid content-using the Boehringer Mannheim enzyme test and spectrophotometry;

- tartaric acid content-the vanadate ions of the reagent added to the wine combined with the tartrate ions in the wine turn the liquid into an orange-colored complex.

We measured the intensity of the color, which is proportional to the concentration level of the tartaric acid (MSZ-9489-78).

Examining the polyphenol content in wines:

- Overall polyphenol content defined using the Folin-Ciocalteu reagent, calibrated for gallic acid, in accordance with the Hungarian standard no. MSZ-9474-80;

- Leucoanthocyanin content examined after warming butanol-hydrochloric acid containing iron (II) sulphate, with spectrophotometry (ratio 40:60);

- To measure the catechin concentration, we used the Rebelein (1965) method, where the liquid, reacting with vanillin, gives a colored product. Other, routine analytical examinations: sulfurous acid content (free/all)—MSZ 9465-85, and volatile acid content-MSZ 9473-87;

- To define the overall polyphenol content: Folin-Ciocalteu reagent, calibrated for gallic acid;

- The amount of leucoanthocyanins was defined by heating hydrochloric acid butanol containing iron (II) sulphate, proportion 40:60, using spectrophotometry, based on the Flanzy (1970) modified method;

- The catechin content in wine diluted in alcohol, after inducing a chemical reaction with vanillin sulphuric acid, on $500 \mathrm{~nm}$, using spectrophotometry; 
- $\quad$ The simple phenol component was defined using the HPLC technique. It is possible to establish the level of the cinnamon acid derivatives, like coffee acid or their esters, obtained with tartaric acid, such as caftaric acid, employing a diode string detector;

- We defined the cis-trans-resveratrol content of the wines with direct injection, through the HPLC method;

- Measuring the quercetin and quercetin glucoside content using the HPLC technique, with a Purospher RP18, $250 \times 4(5 \mu \mathrm{m})$ (Merck, Germany) column, the flow rate was $0.45 \mathrm{~mL} / 1$, the column $30^{\circ} \mathrm{C}$, and detection by a diode array detector at $370 \mathrm{~nm}$;

- Biogenic amines defined with the HPLC equipment (HP 1090 HPLC) Nucleosil 100 C$18(250 \times 4 \mathrm{~mm})$, with an HP 1046 Fluorescens detector at $1 \mathrm{~mL} / \mathrm{min}$ flowrate under a $30{ }^{\circ} \mathrm{C}$ column ( $\lambda$ em: $340 \mathrm{~nm} ; \lambda$ ex: $440 \mathrm{~nm}$ ). Eluent composition A solution $0.08 \mathrm{M}$ acetic acid, B solution acetonitrile (HPLC quality).

\subsection{Statistical Analyses}

The results were imported into and evaluated in the programs Microsoft Word for Mac and Excel for Mac. The results were evaluated by $t$-tests $(\alpha=0.95)$.

\section{Results}

Results of the primer analysis are summarized in Table 1 . The values show that there is a significant difference among the samples regarding alcohol and residual sugar concentration. In case of the control samples, a regular, normal fermentation is detectable, where the residual sugar content is only $2 \mathrm{~g} / \mathrm{L}$. Organic yeast showed partial effectiveness only, as $63.4 \mathrm{~g} / \mathrm{L}$ of sugar remained in the wine. This was the reason for the significant differences in alcohol and residual sugar content.

Table 1. Obtained results of the chemical analyses of wines produced with organic yeast.

\begin{tabular}{ccccc}
\hline & \multicolumn{2}{c}{ Control } & \multicolumn{2}{c}{ Organic Yeast } \\
\hline & Average & Deviation & Average & Deviation \\
Free/overall $\mathrm{SO}_{2}(\mathrm{mg} / \mathrm{L})$ & $46 / 105$ & & $55 / 104$ & \\
Titratable acidity (g/L) & 7.1 & \pm 1.04 & 7 & \pm 0.55 \\
pH value & 3.36 & \pm 0.13 & 3.31 & \pm 0.08 \\
Alcohol (v/v\%) & 13.89 & \pm 0.76 & 9.77 & \pm 1.2 \\
Sugar (g/L) & 2.2 & \pm 0.55 & 6.34 & \pm 0.84 \\
Volatile acid (g/L) & 0.37 & \pm 0.13 & 0.59 & \pm 0.15 \\
Glycerin (g/L) & 6.16 & \pm 0.16 & 6.53 & \pm 0.08 \\
\hline
\end{tabular}

In wine making technology, the volatile acid content is an especially important factor. Our present study showed that all the problematic values were under the critical limit $(1 \mathrm{~g} / \mathrm{L})$. The results of the biogenic amine content in "Bianca" wines, 2015-2017, are shown in Figure 1. The glycerin content correlated with the literary values, since its well known that the glycerin-pyruvic acid transformation results in a 6-10 g/L concentration.

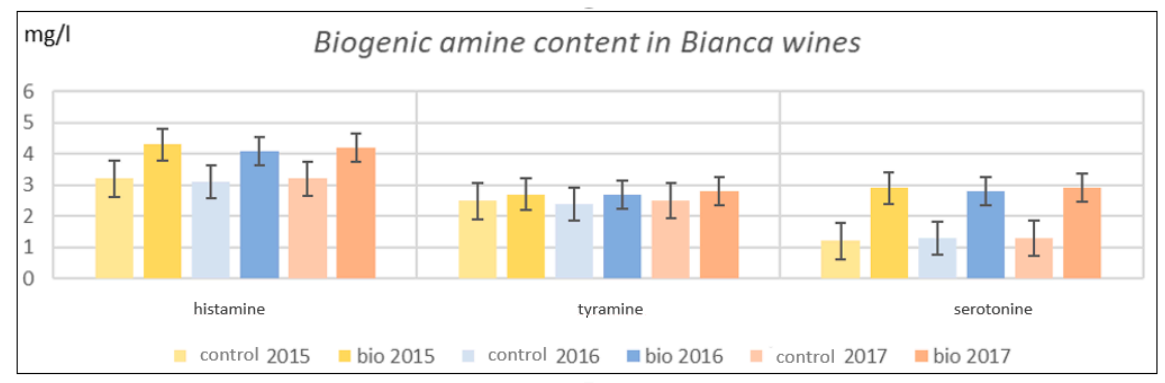

Figure 1. Biogenic amine content in "Bianca" wines, 2015-2017.

The histamine, tyramine, and serotonin concentration, due to their physiological effect, are presented in the first diagram. 
In our study, the impact of organic yeast on biogenic amine formation regarding three important compounds (histamine, tyramine and serotonin) was examined. We found significant differences in the samples produced with organic yeast. In terms of physiological effect, the organic yeast produced serotonin in a higher concentration. We can conclude that the level was below the critical $5 \mathrm{mg} / \mathrm{L}$, as suggested in a literature review [39], and it is in accordance with the health prescriptions concerning the three most important biogenic amines.

In the case of the histamine concentration, it can be stated that there is no relevant difference between the control and the organic samples at the $95 \%$ significance level. The histamine concentration is not allowed to exceed $5 \mathrm{mg} / \mathrm{L}$ in wines, and Figure 2 shows that the histamine levels in the two samples were well below that.

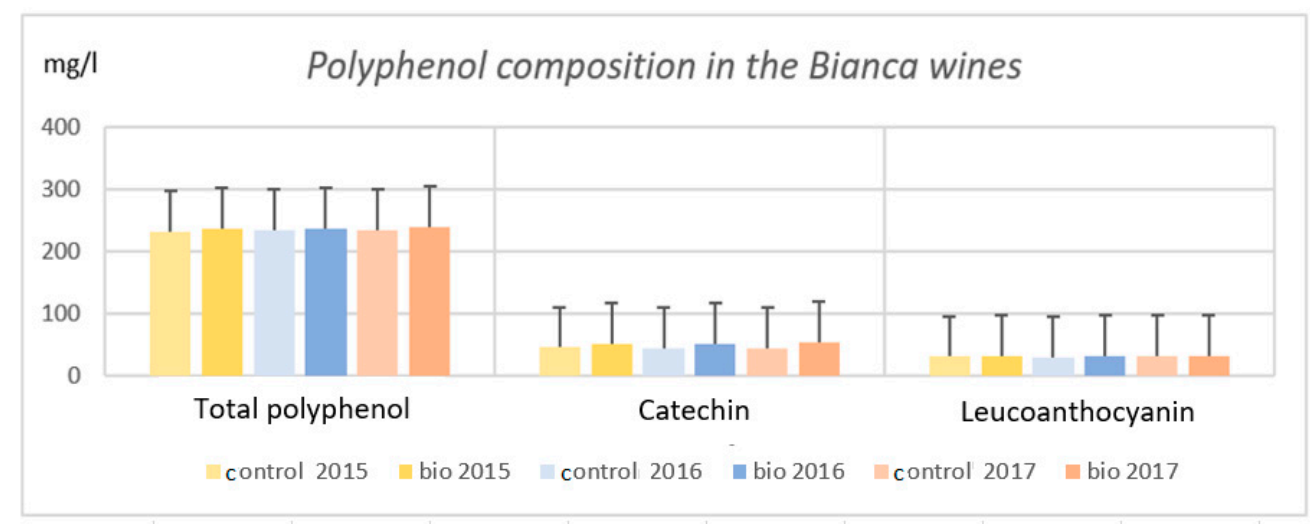

Figure 2. Polyphenol composition in the "Bianca" wines, 2015-2017.

The tyramine concentration changed according to the relevant literature [40]. In neither sample were we able to detect a statistical difference. The serotonin content changed as expected, and based on the statistical test, we can state that there is a significant difference between the traditionally produced wine samples and those fermented with organic yeast $(\mathrm{a}=0.05 ; \mathrm{s} 2=0.49 ; \mathrm{DF}=5)$.

In case of the other biogenic amines, there are relevant differences between the samples produced with organic and traditional yeast fermentation (Table 2.). The amount of amines, such as cadaverine, putrescine, and ethylamine, could be measured in significant quantities $(\mathrm{a}=0.05 ; \mathrm{s} 2=0.22 ; \mathrm{DF}=5)$. At the same time, the methylamine level was higher in the control sample $(6.5 \mathrm{mg} / \mathrm{L})$. Based on our measurements, we could only prove significant differences between the samples in case of the methylamine concentration. In turn, 2phenylethylamine could not be detected in any of the samples.

Table 2. Results of analyses: wines produced with organic and traditional yeast.

\begin{tabular}{ccccccc}
\hline $\mathbf{2 0 1 5}$ & $\mathbf{2 0 1 5}$ & $\mathbf{2 0 1 6}$ & $\mathbf{2 0 1 6}$ & $\mathbf{2 0 1 7}$ & $\mathbf{2 0 1 7}$ & \\
\hline (mg/L) & Control 2015 & Bio 2015 & Control 2016 & Bio 2016 & Control 2017 & Bio 2017 \\
Methylamine & 6.5 & 3.7 & 6.2 & 3.5 & 6.4 & 3.8 \\
Cadaverine & 1.8 & 3.2 & 1.7 & 3.2 & 1.8 & 3.1 \\
Putrescine & 0.98 & 1.1 & 0.95 & 1.1 & 0.94 & 1.3 \\
Ethylamine & 0.87 & 2.4 & 0.85 & 2.4 & 0.84 & 2.5 \\
\hline
\end{tabular}

We could not find significant differences between the samples regarding the biogenic amine composition, except for the methylamine concentration. Our results show that these yeast varieties can ensure the same quality as traditional yeast stocks. We consider it as a priority to analyze the so-called organic yeasts, as they can be the base of organic grape growing and organic wine production. Our results showed that there was no significant difference to be described, not even at a very low confidence level $(\mathrm{a}=0.2)$, in any of the three vintages. 
Tyrosol is formed only through alcoholic fermentation, and the amount and formation of tyrosine is influenced by the yeast. The tyrosol level was high in the wines produced with organic yeast in all three vintages (Figure 3 ).

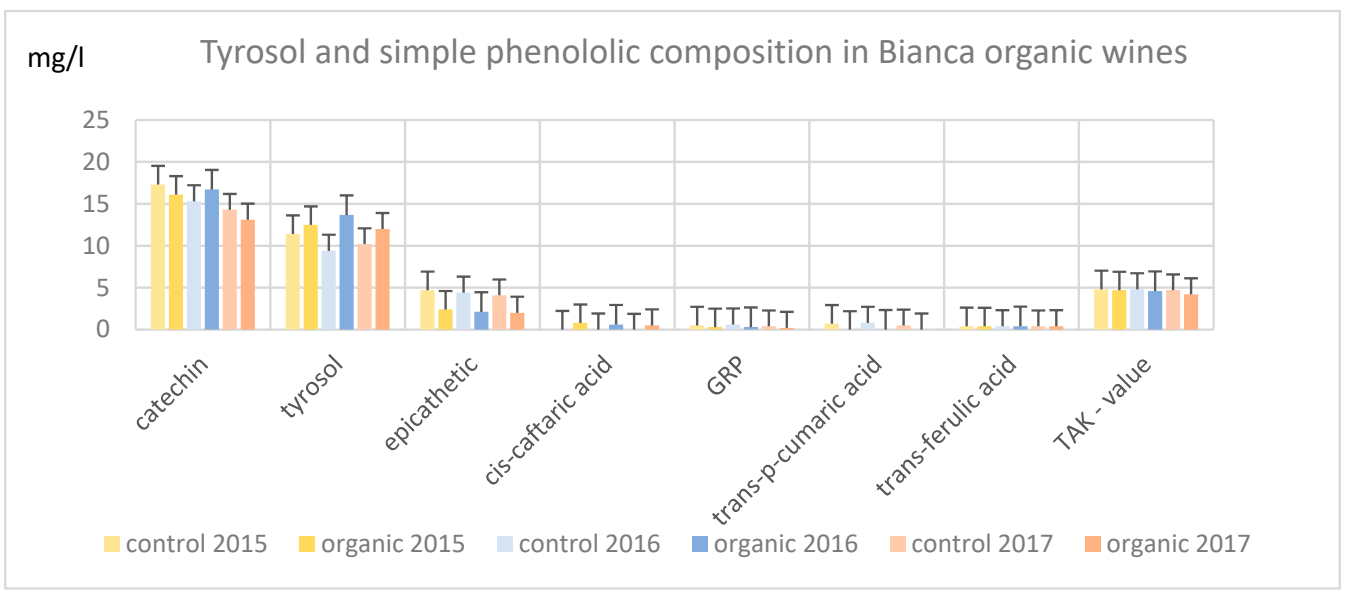

Figure 3. Tyrosol and simple phenolic composition in "Bianca" organic wines.

The overall antioxidant capacity value developed evenly as it is formed from polyphenol, so there is no difference. As for epicatechin, in all three vintage years we measured lower values in the organic vines (Table 3).

Table 3. Tyrosol and simple phenolic composition in the "Bianca" organic wines, 2016-2017.

\begin{tabular}{|c|c|c|c|c|c|c|}
\hline 2015 & 2015 & 2016 & 2016 & 2017 & 2017 & \\
\hline$(\mathrm{mg} / \mathrm{L})$ & Control & Bio & Control & Bio & Control & Bio \\
\hline Catechin & 17.3 & 16.1 & 15.3 & 16.7 & 14.3 & 13.1 \\
\hline Tyrosol & 11.4 & 12.49 & 9.4 & 13.66 & 10.2 & 11.99 \\
\hline Epicatechin & 4.7 & 2.4 & 4.4 & 2.1 & 4.1 & 2 \\
\hline Cisz-caftaric acid & 0 & 0.8 & 0 & 0.6 & 0 & 0.5 \\
\hline Trans-caftaric acid & 0 & 0 & 0 & 0 & 0 & 0 \\
\hline Cis-caftaric acid & 0 & 0 & 0 & 0 & 0 & 0 \\
\hline GRP & 0.5 & 0.3 & 0.6 & 0.3 & 0.4 & 0.2 \\
\hline Trans coumaric acid & 0 & 0 & 0 & 0 & 0 & 0 \\
\hline Fertaric acid & 0 & 0 & 0 & 0 & 0 & 0 \\
\hline Caffeic acid & 0 & 0 & 0 & 0 & 0 & 0 \\
\hline Trans-p-coumaric acid & 0.7 & 0 & 0.8 & 0 & 0.5 & 0 \\
\hline Trans-ferulic acid & 0.4 & 0.4 & 0.4 & 0.4 & 0.4 & 0.4 \\
\hline TAK-value & 4.8 & 4.7 & 4.8 & 4.6 & 4.7 & 4.2 \\
\hline
\end{tabular}

In the samples produced with organic yeast, the catechin, leucoanthocyanin, and overall polyphenol concentration values supported the data in the relevant literature [41]. There was no significant difference between the polyphenol content in the samples of the control or the treated wines. The tyrosol concentration was higher in the organic samples. Regarding the simple phenol composition, there was no relevant difference between the samples. We can state that a considerable difference between the organic and the control samples was in the polyphenol and simple phenol composition and in the amount of tyrosol, which is the most important finding.

The results of the analysis turned out as expected. There was no considerable difference among the samples. We detected a great difference in polyphenol composition, which is a result of the interaction of the yeast with the polyphenol.

The biogenic amine content in the examined wines does not differ from that of the conventional wines.

The biogenic amine composition in the resistant varieties corresponds to the composition of the biogenic amines in the international varieties. The organic yeast also has an 
influence on the production of amines, but there is no clear distinction compared to the "traditional" types of yeast; thus, further examinations are necessary.

From the results of our research, we can conclude that organic yeasts cause significant differences in the glycerin concentration and in the residual sugar content of the samples. The volatile acid content was measured below the critical level of $1.0 \mathrm{~g} / \mathrm{L}$ [42] in all cases.

\section{Discussion}

In this study, we aimed to find out what kind of "Bianca" wine can be produced when using organic yeast, what are the dynamics of the resulting alcoholic fermentation, and whether this method is suitable for industrial production as well. We fermented wines from the "Bianca" juice samples three times where model chemical solutions were applied.

Our present study showed that all the problematic values were under the critical limit $(1 \mathrm{~g} / \mathrm{L})$, although the organic samples resulted in a significantly higher level than the conventional wines.

The glycerin content correlated with the literature values, since it is well known that the glycerin-pyruvic acid transformation results in a 6-10 g/L concentration.

In our research we aimed to find out how organic yeast influenced biogenic amine formation, regarding three important compounds: histamine, tyramine, and serotonin. We measured significant differences in the samples produced with organic yeast, where the values were higher.

We could not find significant differences in biogenic amine composition between the samples, except for the methylamine concentration. Our results showed that these yeast varieties could ensure the same quality as traditional yeast stocks.

There was no significant difference between the polyphenol content in the wines from the control or the treated items. The tyrosol concentration was higher in the organic samples. Regarding the simple phenol composition, there was no relevant difference among the samples. We can state that a considerable difference between the organic and control samples was in the polyphenol and simple phenol composition and in the amount of tyrosol; the latter is the most important finding.

\section{Conclusions}

Among the physiologically effective compounds, the biogenic amine composition was examined. The most important allergenic, histamine, was measured within the approved range $(10 \mathrm{mg} / \mathrm{L})$. The "Bianca" grape variety is perfectly suitable to produce organic wine regarding the biogenic amine content. In case of the other amines, we concluded that their values correlate with the values previously published in the relevant literature sources, and there is no significant difference either as a result of using organic yeast or the vine variety "Bianca" as a basic material. Regarding the polyphenol composition, we can conclude that it is suitable to produce high-quality "Bianca" organic wine. Following this project, we will examine the possibility of meeting the modern oenological technology requirements of a widespread grape variety "Bianca" in Hungary, in order to find what additional specifications we can define to further increase the market of this variety.

Author Contributions: Conceptualization, D.N.S.; data curation, B.N., Z.V., R.M., N.K., Á.S. and D.N.S.; formal analysis, R.M. and N.K.; investigation, N.K.; methodology, D.N.S.; project administration, Á.S.; resources, Á.S.; supervision, B.N. and D.N.S.; validation, D.N.S.; writing-original draft, B.N., Z.V. and R.M.; writing-review and editing, Z.V. and R.M. All authors have read and agreed to the published version of the manuscript.

Funding: This research was supported by the Hungarian Ministry for Innovation and Technology within the framework of the Thematic Excellence Program (TUDFO/51754/2019-ITM) in the scope of "Adaptation to the changing environment in the vitivinicultural sector".

Institutional Review Board Statement: "Not applicable" for studies not involving humans or animals.

Informed Consent Statement: "Not applicable" for studies not involving humans. 
Data Availability Statement: The data presented in this study are available on request from the corresponding author.

Conflicts of Interest: The authors declare no conflict of interest.

\section{References}

1. A Tanács 834/2007/EK Rendelete (2007. Június 28.) az Ökológiai Termelésről és az Ökológiai Termékek Címkézéséről és a 2092/91/EGK Rendelet Hatályon Kívül Helyezéséről. Available online: https:/ / eur-lex.europa.eu/legal-content/hu/TXT/?uri= CELEX\%3A32007R0834 (accessed on 7 December 2020).

2. Bardócz, S. Polyamines in food and their consequences for food quality and human health. Trends Foof Sci. Technol. 1995, 6 , 341-346. [CrossRef]

3. Berridge, K.C.; Robinson, T.E.; Aldridge, J.W. Dissecting components of reward: 'liking', 'wanting', and learning. Curr. Opin. Pharmacol. 2009, 9, 65-73. [CrossRef] [PubMed]

4. Biró, G. Élelmiszer-Higiénia; Agroinform Kiadó: Budapest, Hungary, 2014.

5. Bíró, K.; Mercz, Á. A Bor Készitése és Kezelése; Mezőgazdasági Kiadó: Budapest, Hungary, 1953; pp. $211-215$.

6. Bódog, A. Hisztaminintolerancia. Új Diéta 2013, 22, 10-12.

7. Boér, K. A Hisztamin Metabolizmus és a Hisztamin Receptorok Változása Humán Colorectalis Tumorokban. Ph.D. Thesis, Semmelweis Egyetem, Budapest, Hungary, 2007; pp. 1-86.

8. Cottrell, R.C.; Walters, D.G.; Young, P.J.; Phillips, J.C.; Lake, B.G.; Gangolli, S.D. Studies of the urinary metabolites of Nnitrosopyrrolidine in the rat. Toxicol. Appl. Pharmacol. 1980, 54, 368-376. [CrossRef]

9. De Freitas, V. Revisiting Wine Polyphenols Chemistry in Relation to Their Sensory Characteristics. Recent Adv. Polyphen. Res. 2019, 6, 263-284.

10. Del Rio, B.; Redruello, B.; Linares, D.M.; Ladero, V.; Ruas-Madiedo, P.; Fernandez, M.; Martin, M.C.; Alvarez, M.A. The biogenic amines putrescine and cadaverine show in vitro cytotoxicity at concentrations that can be found in foods. Sci. Rep. 2019, 9, 120. [CrossRef]

11. Eine neue Ära: Bio-Hefe. 2017. Available online: http://schrotundkorn.de/ernaehrung/lesen/sk971202.html (accessed on 7 December 2020).

12. Esposito, F.; Montuori, P.; Schettino, M.; Velotto, S.; Stasi, T.; Romano, R.; Cirillo, T. Level of Biogenic Amines in Red and White Wines, Dietary Exposure, and Histamine-Mediated Symptoms upon Wine Ingestion. Molecules 2019, 24, 3629. [CrossRef]

13. Gillis, M. Phenylethylamine: More Than Just a Pea-Sized Neurochemical. Available online: https://pdfs.semanticscholar.org/ 3b31/cf1ce7062527244b1a9b034049dba9c14fca.pdf (accessed on 1 June 2020).

14. Gyires, K.; Fürst, Z. A Farmakológia Alapjai; Medicina Kiadó: Budapest, Hungary, 2011; p. 1244.

15. Hencshke, P.A.; Jiranek, V. Yeasts-metabolism of nitrogen compounds. In Wine Microbiology and Biotechnology; CRC Press: Boca Raton, FL, USA, 1993; pp. 77-164.

16. Hoyles, L.; Swann, J. Influence of the Human Gut Microbiome on the Metabolic Phenotype. In The Handbook of Metabolic Phenotyping; Lindon, J., Nicholson, J., Holmes, E., Eds.; Elsevier (eBook): Amsterdam, The Netherlands, 2019 ; pp. 535-560.

17. Available online: https://schrotundkorn.de/artikel/hefe-muss-jetzt-bio-sein (accessed on 14 December 2020).

18. Irsfeld, M.; Spadafore, M.; Prüß, B.M. $\beta$-phenylethylamine, a small molecule with a large impact. WebmedCentral $2013,4,4409$.

19. Janssen, P.A.; Leysen, J.E.; Megens, A.A.; Awouters, F.H. Does phenylethylamine act as an endogenous amphetamine in some patients? Int. J. Neuropsychopharmacol. 1999, 2, 229-240. [CrossRef]

20. Johnson, M.P.; Hoffman, A.J.; Nichols, D.E. Effects of enantiomers of MDA, MDMA and related analogues on [3 H]serotonin and $\left[{ }^{3} \mathrm{H}\right]$ dopamine release from superfused rat brain slices. Eur. J. Pharmacol. 1986, 132, 269-276. [CrossRef]

21. Kállay, M. Magyar Borok Biogén Amin Tartalmának és Azok Változásának Tanulmányozása, Különös Tekintettel a Hisztamin és a Tiramin Koncentrációjára. Ph.D. Thesis, REAL-d, Southampton, UK, 1991.

22. Kállay, M. Borászati Kémia; Mezőgazda Kiadó Kft: Budapest, Hungary, 2010.

23. Komlósi, G. Humán Agykérgi Neuronhálózatok Múködése és Szerotonerg Szabályzása. Ph.D. Thesis, Szegedi Tudományegyetem, Szeged, Hungary, 2012. Available online: http://doktori.bibl.u-szeged.hu/id/eprint/1625/1/Disszertáció_Komlósi_Gergely.pdf (accessed on 7 December 2020).

24. Köllő, M. A K 4 Feszültségfüggő Káliumcsatorna Alegységek Sejtfelszíni Eloszlása Központi Idegrendszeri Sejteken. Ph.D. Thesis, Semmelweis Egyetem, Budapest, Hungary, 2008.

25. Martuscelli, M.; Arfelli, G.; Manetta, A.C.; Suzzi, G. Biogenic amines content as a measure of the quality of wines of Abruzzo (Italy). Food Chem. 2013, 140, 590-597. [CrossRef] [PubMed]

26. National Library of Medicine. Az Egyes biogén Aminok leírása Angol Nyelven. National Institutes of Health. 2020. Available online: https: / /www.nlm.nih.gov / (accessed on 15 April 2020).

27. Oenoferm ${ }^{\circledR}$ Bio, Selection Klingelberg, Zertifizierte Biologische Trockenreinzuchthefe für Wein und Sekt aus ökologischem Anbau. 2015. Available online: http:/ / www.erbsloeh.com/de/produkte/wein/bio_vinifikation (accessed on 7 December 2020).

28. Olfson, M.; Huang, C.; Gerhard, T.; Winterstein, A.G.; Crystal, S.; Allison, P.D.; Marcus, S.C. Stimulants and cardiovascular events in youth with attention-deficit/hyperactivity disorder. J. Am. Acad. Child Adolesc. Psychiatry 2012, 51, 147-156. [CrossRef] [PubMed] 
29. Premont, R.T.; Gainetdinov, R.R.; Caron, M.G. Following the trace of elusive amines. Proc. Natl. Acad. Sci. USA 2001, 98, 9474-9475. [CrossRef] [PubMed]

30. Sánchez-Pérez, S.; Comas-Basté, O.; Rabell-González, J.; Veciana-Nogués, M.T.; Latorre-Moratalla, M.L.; Vidal-Carou, M.C. Biogenic Amines in Plant-Origin Foods: Are They Frequently Underestimated in Low-Histamine Diets? Foods 2018, 7, 205.

31. Shalaby, A.R. Significance of biogenic amines to food safety and human health. Food Res. Int. 1996, 29, 675-690. [CrossRef]

32. Smith, T.A. Amines in Food. Food Chem. 1980, 6, 169-200. [CrossRef]

33. Stanbury, P.F.; Whitaker, A.; Hall, S.J. Principles of Fermentation Technology, 2nd ed.; Elsevier (eBook): Amsterdam, The Netherlands, 1995; ISBN 075064501.

34. Til, H.P.; Falke, H.E.; Prinsena, M.K.; Willems, M.I. Acute and subacute toxicity of tyramine, spermidine, spermine, putrescine and cadaverine in rats. Food Chem. Toxicol. 1997, 35, 337-348. [CrossRef]

35. Tomar, P.C.; Lakra, N.; Mishra, S.N. Cadaverine: A lysine catabolite involved in plant growth and development. Plant Signal. Behav. 2013, 8, e25850. [CrossRef]

36. Vos, P.J.A.; Gray, R.S. The origin and control of hydrogen sulfide diuring fernetation of grape must. Am. J. Enol. Vitic. 1979, 30, 187-197.

37. Wang, X.; Li, J.; Dong, G.; Yue, J. The endogenous substrates of brain CYP2D. Eur. J. Pharmacol. 2014, 724, 211-218. [CrossRef]

38. Wassenberg, T.; Willemsen, M.A.; Geurtz, P.B.; Lammens, M.; Verrijp, K.; Wilmer, M.; Lee, W.T.; Wevers, R.A.; Verbeek, M.M. Urinary dopamine in aromatic L-amino acid decarboxylase deficiency: The unsolved paradox. Mol. Genet. Metab. 2010, 101, 349-356. [CrossRef] [PubMed]

39. World Health Organization. Critical Review of Ketamine. 2006. Available online: https://www.who.int/medicines/areas/ quality_safety/4.3KetamineCritReview.pdf (accessed on 1 June 2020).

40. Young, S.N. How to increase serotonin in the human brain without drugs. J. Psychiatry Neurosci. 2007, 32, 394-399. [PubMed]

41. Yu, A.M.; Granvil, C.P.; Haining, R.L.; Krausz, K.W.; Corchero, J.; Küpfer, A.; Idle, J.R.; Gonzalez, F.J. The relative contribution of monoamine oxidase and cytochrome p450 isozymes to the metabolic deamination of the trace amine tryptamine. J. Pharmacol. Exp. Ther. 2003, 304, 539-546. [CrossRef] [PubMed]

42. Zeisel, S.H.; Da Costa, K.A.; Franklin, P.D.; Alexander, E.A.; Lamont, J.T.; Sheard, N.F. A Beiser Choline, an essential nutrient for humans. FASEB J. 1991, 5, 2093-2098. [CrossRef] 